\title{
SPATIAL ANALYSIS OF ECONOMIC DEVELOPMENT OF SELECTED REGIONS OF THE EU COUNTRIES FROM A DYNAMIC PERSPECTIVE
}

\author{
ANALIZA PRZESTRZENNA ROZWOJU GOSPODARCZEGO REGIONÓW \\ WYBRANYCH KRAJÓW EUROPEJSKICH W UJĘCIU DYNAMICZNYM
}

Department of Statistics, Econometrics and Mathematics, University of Economics in Katowice 1 Maja 50, 40-287 Katowice, Poland, e-mail: ewa.pospiech@ue.katowice.pl, adrianna.mastalerz-kodzis@ue.katowice.pl

\begin{abstract}
Streszczenie. W artykule poddano analizie charakterystykę, która jest jednym z najczęściej stosowanych agregatów do oceny poziomu rozwoju gospodarczego - PKB na jednego mieszkańca. Rozważano tę zmienną w dwóch ujęciach - jako PKB podane w EUR oraz według PPS. Analiza przeprowadzona została dla sześciu państw UE, w ujęciu regionalnym, na podstawie podziału według systemu NUTS 2. Na wstępie badano, jak kształtowało się PKB na jednego mieszkańca ( $w$ obydwu ujęciach) na przestrzeni rozpatrywanych dziesięciu lat. Zaobserwowano istotne korzystne zmiany wielkości PKB w kolejnych latach. Następnie badano występowanie autokorelacji przestrzennej (globalnej oraz lokalnej) dla rozważanych cech. Analiza ta ukazała we wszystkich latach silną dodatnią autokorelację przestrzenną oraz występowanie dwóch zdecydowanych skupień zlokalizowanych odpowiednio na ścianie wschodniej badanego obszaru (skupienie o niższych od średniej poziomach PKB na mieszkańca) oraz w części południowo-zachodniej (skupienie o wysokich poziomach PKB na mieszkańca). Przeprowadzone analizy potwierdziły istotność czynnika przestrzennego w analizach rozwoju gospodarczego.
\end{abstract}

Key words: economic development, global and local statistics, regional analysis, spatial autocorrelation.

Słowa kluczowe: analizy regionalne, autokorelacja przestrzenna, rozwój gospodarczy, statystyki globalne i lokalne.

\section{INTRODUCTION}

In the analysis of socio-economic phenomena such as demographic processes, electoral preferences, real estate rating, as well as unemployment rate, economic development and the like, spatial methods are being increasingly used (Pietrzykowski 2011; Zeug-Żebro 2014; Pośpiech 2015; Pośpiech and Mastalerz-Kodzis 2015). These methods enable identification of spatial interdependences (if such do exist) of a given variable within a considered area, and also in relation to neighbouring areas. Thanks to these methods the importance of the spatial factor is not overlooked, and it can significantly help explain the variability of the examined phenomena and also provide a valuable policy guideline for authorities. The significance of including spatial connections was pointed out by Waldo Tobler who formed the law according to which neighbouring locations show a greater similarity concerning studied features than 
locations further apart from each other (Tobler 1970). The importance of spatial connections was also emphasized by Paelinck and Klaassen (Paelinck and Klaassen 1983). Therefore, for studies concerning feature values present in certain locations it is definitely worth to apply spatial methods.

The article focuses on economic development of selected regions of the EU countries. Economic development - as well as growth constitute extremely important concepts of the balanced growth theory, the aim of which is harmonious development of natural, technological, economic and socio-cultural subsystems. Such a development is linked to, inter alia, a better satisfaction of population's needs, enhanced social justice and true environmental sustainability (Makro- i mikroekonomia. Podstawowe problemy współczesności 2013). The particular importance of this phenomenon justifies the choice of the study subject.

The aim of the paper is to identify spatial interdependence occurring among some regions of selected European countries in relation to GDP per inhabitant, which is one of the most frequently used aggregate measures of economic development. This analysis covers a span of ten years, which is a period sufficient to identify existing tendencies.

\section{MEASURES USED IN THE STUDY}

The study employed descriptive statistics, spatial statistical and econometric tools. We included local and global Moran's statistics that measure spatial autocorrelation which demonstrates the existence of spatial interdependence within feature locations and in relation to neighbouring areas. Moran's global statistic $I$ is defined on the base of the following formula (Cliff and Ord 1973; Ekonometria przestrzenna 2010; Kopczewska 2011):

$$
I=\frac{n}{S_{0}} \cdot \frac{\mathbf{z}^{\top} \mathbf{W} \mathbf{z}}{\mathbf{z}^{\top} \mathbf{z}}
$$

where:

$n-$ the number of feature regions,

$\mathbf{z}$ - the column vector of values expressed as: $z_{i}=x_{i}-\bar{x}, i=1, \ldots, n$,

$x_{i}, x_{j}-$ observations made in regions,

$\bar{x}-$ the arithmetic mean (for all observations in all regions),

$S_{0}$ - the sum-total of weights matrix elements, $S_{0}=\sum_{i=1}^{n} \sum_{j=1}^{n} w_{i j}$,

$\mathbf{W}$ - the weights matrix $w_{i j}, i=1, \ldots n, j=1, \ldots, n$, of the following elements

$$
w_{i j}= \begin{cases}1, & \text { when objects } i \text { and } j \text { share a border } \\ 0, & \text { when objects } i \text { and } j \text { do not share a border } \\ 0, & \text { for diagonal elements }\end{cases}
$$

Negative or positive Moran's index values ${ }^{1}$ indicate the absence $\left(H_{0}\right)$ or presence $\left(H_{1}\right)$ of spatial autocorrelation.

The values of statistic $I$, which in a large sample is near zero, are compared with the expected value $\mathrm{E}(I)$. We can state:

\footnotetext{
${ }^{1}$ The statistic is described, inter alia, in Ekonometria przestrzenna (2010).
} 
- the absence of spatial autocorrelation, i.e. random distribution of the variable values in feature locations $\left(I \approx-\frac{1}{n-1}\right)$,

- positive autocorrelation, i.e. concentration of similar values in feature locations $\left(I>-\frac{1}{n-1}\right)$,

- negative autocorrelation, i.e. clustering of dissimilar, that is high and low values in feature locations $\left(I<-\frac{1}{n-1}\right)$.

Moran's local statistic $l_{i}$ allows to identify clusters of high or low variable values and indicate outliers (Anselin 1995; Kopczewska 2011; Ekonometria przestrzenna 2010). The following formula is used:

$$
I_{i}=\frac{\left(x_{i}-\bar{x}\right) \sum_{j=1}^{n} w_{i j}^{*}\left(x_{j}-\bar{x}\right)}{\sum_{i=1}^{n}\left(x_{i}-\bar{x}\right)^{2}}
$$

where:

$$
\begin{aligned}
& w_{i j}^{*} \text { - elements of the weights matrix given from the formula } \\
& w_{i j}^{*}=\frac{w_{i j}}{\sum_{j=1}^{n} w_{i j}}
\end{aligned}
$$

Significant values of $I_{i}$ statistic imply that:

- region $i$ is surrounded by regions with similar values of the considered feature (positive values of the statistic) - clusters are formed,

- region $i$ is surrounded by different values of a given feature (negative values of the statistic) - region $i$ is an outlier.

\section{EMPIRICAL ANALYSIS}

The empirical analysis was conducted for the period of 2005-2014. The study focused on selected NUTS level 2 regions in the European Union. Six countries were taken into account: Austria, the Czech Republic, Germany, Hungary, Poland and Slovakia.

The considerations involved the analysis of the variable, which is commonly considered as the best tool to measure economic development - GDP per inhabitant. The study used two of its variants:

- Regional GDP (euro per inhabitant) - GDP_Euro,

- Regional GDP (PPS per inhabitant) - GDP_PPS.

The first of the variables expresses the value of GDP per one inhabitant in euro currency, whilst the other one determines the value of GDP per one inhabitant, but it is stated according to the Purchasing Power Standard (PPS). PPS is an artificial currency unit with which, theoretically, it is possible to purchase the same amount of goods and services in every country of the EU. PPS is a term used for the common currency in which national accounts aggregates are expressed after adjustment for price level differences with the use of PPPs (Purchasing Power Parities). Thus GDP per capita in PPS is a meaningful tool for cross-country comparisons. The data come from the Eurostat database, whilst the figures and calculations were developed using MS Excel and the R CRAN package. 
The first stage of the analysis is the presentation of the variables over three selected years of the research period. The chosen years are: 2005 - the first year examined, $2009-$ year after the onset of the global economic crisis, 2014 - last year covered by the study. Aiming to present the development of the situation over those years, basic descriptive characteristics for the entire study period were calculated and collated with the data for the years listed. The descriptive statistics obtained are presented in Table 1.

Table 1. Descriptive characteristics for the period of 2005-2014

\begin{tabular}{|l|c|c|}
\hline \multirow{2}{*}{\multicolumn{1}{|c|}{ Characteristics }} & \multicolumn{2}{c|}{ Values of variables } \\
\cline { 2 - 3 } & GDP_Euro & GDP_PPS \\
\hline Minimum (min.) & 4500 & 8100 \\
\hline Mean (mean) & 22564 & 24226.1 \\
\hline Standard deviation (sd) & 12346 & 9863.6 \\
\hline Maximum (max.) & 59000 & 56600 \\
\hline
\end{tabular}

These values were used to define sections of typical values (above and below the average), as well as of the lowest and the highest GDP levels in the considered regions.

The situation for the selected years was as follows (Fig. 1, 2).
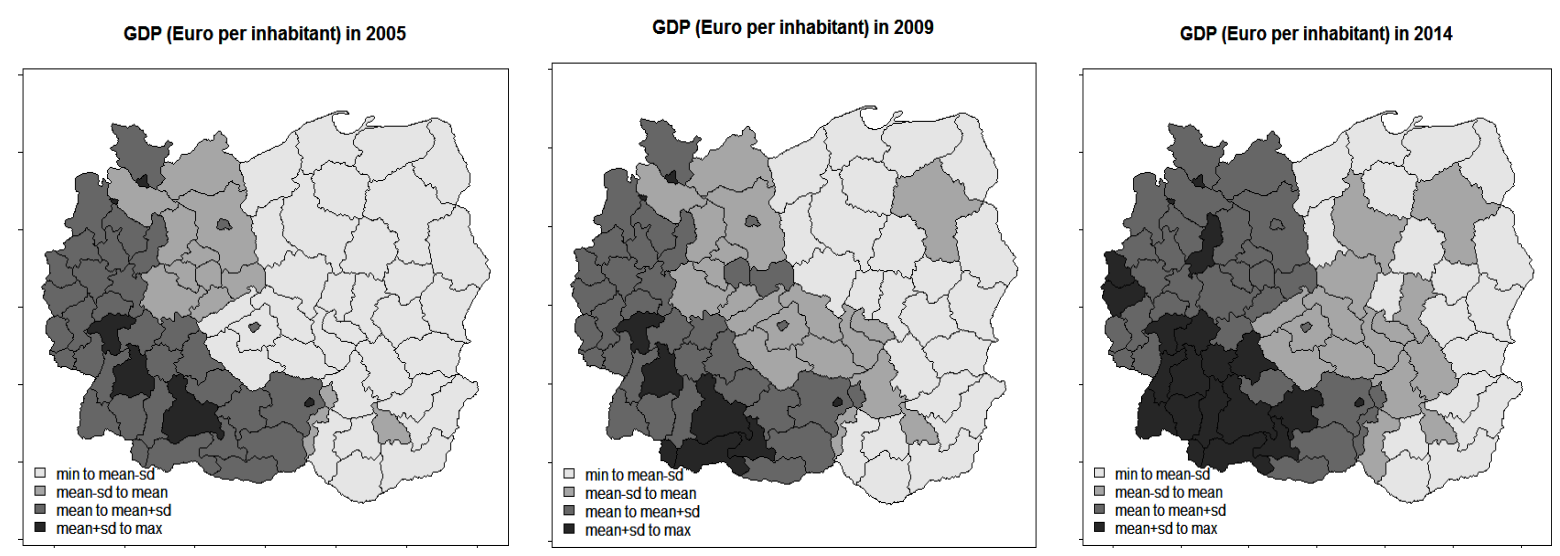

Fig. 1. GDP, euro per inhabitant $(2005,2009,2014)$
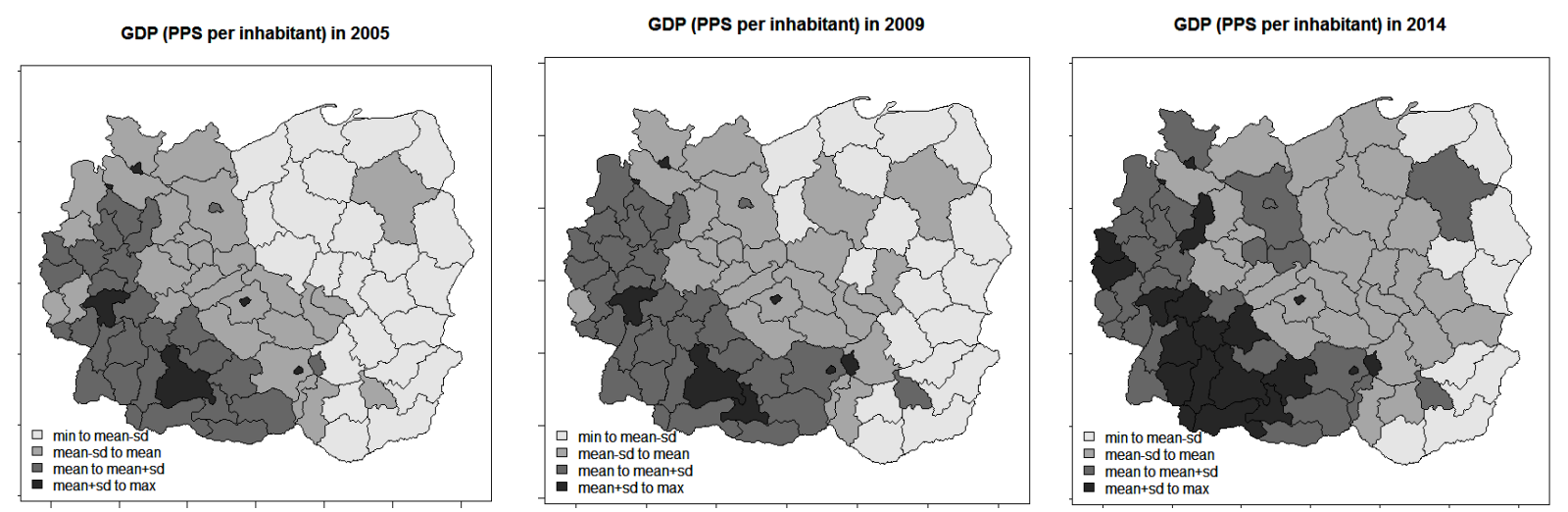

Fig. 2. GDP, PPS per inhabitant $(2005,2009,2014)$ 
When we look at the development of GDP per inhabitant in euro, we can easily notice the dark-shaded regions (highest values, above the average) in the west and south-west, the light grey colour marking the central regions (typical values, below the average) and the lightest shade of grey marking the eastern, southern and south-eastern part of the region. Within the study period, however, certain changes are noticeable. The highest values of GDP, higher than the average (which comes as no surprise) are observed for the regions of western Germany and Austria - this situation remained the same over the ten year period. However, changes in GDP values in other regions are also discernible. Typical values (below the average) in 2005 were recorded primarily in eastern Germany regions (also in the Bratislava region). In the second selected year (2009) two regions of eastern Germany recorded a GDP value above the average, and the group of regions featuring typical GDP values, although below the average, was joined by regions of the Czech Republic and one region each from Poland (Mazovia province), Slovakia (Zapadne Slovensko) and Hungary (Kozep-Magyarorszag). Even bigger changes were observed in 2014. The western and south-western part is still an area featuring the highest (above the average) values of GDP per inhabitant, whilst the area of typical regions with GDP below the average increased in size. These regions were joined by the eastern part of Hungary (Nugat-Dunantul), another region of Slovakia (Stredne Slovensko) and three Polish provinces- lower Silesian, Silesian and the Greater Poland province. The findings imply that dynamic and positive changes took place over the study period.

In the case of the second variable the situation is similar, and dynamic changes for the better over the years are even more evident.

The figures clearly illustrate the progression of GDP per capita. The link between GDP value and a particular geographic region is clearly visible.

We decided, however, to conduct an additional analysis using spatial statistical tools, which, as we could assume, would confirm the existence of spatial interdependence but also identify non-typical clusters and regions in relation to the studied variables.

Table 2 presents the values of Moran's global statistics obtained for both variables over the entire study period.

Table 2. Global Moran's / statistics for regions

\begin{tabular}{|c|c|c|c|c|}
\hline \multirow{2}{*}{ Year } & \multicolumn{2}{|c|}{$\begin{array}{c}\text { Global Moran's / statistics } \\
\text { (GDP_Euro) }\end{array}$} & \multicolumn{2}{c|}{$\begin{array}{c}\text { Global Moran's / statistics } \\
\text { (GDP_PPS) }\end{array}$} \\
\cline { 2 - 5 } & $I$ & $p$-value & $I$ & $p$-value \\
\hline 2005 & 0.7132 & $2.2 \mathrm{E}-16$ & 0.5393 & $1.358 \mathrm{E}-15$ \\
\hline 2006 & 0.7137 & $2.2 \mathrm{E}-16$ & 0.5414 & $1.132 \mathrm{E}-15$ \\
\hline 2007 & 0.7036 & $2.2 \mathrm{E}-16$ & 0.5140 & $2.442 \mathrm{E}-14$ \\
\hline 2008 & 0.6855 & $2.2 \mathrm{E}-16$ & 0.5057 & $6.133 \mathrm{E}-14$ \\
\hline 2009 & 0.7014 & $2.2 \mathrm{E}-16$ & 0.4718 & $2.029 \mathrm{E}-12$ \\
\hline 2010 & 0.7000 & $2.2 \mathrm{E}-16$ & 0.4836 & $6.461 \mathrm{E}-13$ \\
\hline 2011 & 0.7045 & $2.2 \mathrm{E}-16$ & 0.4919 & $2.777 \mathrm{E}-13$ \\
\hline 2012 & 0.7117 & $2.2 \mathrm{E}-16$ & 0.4966 & $1.735 \mathrm{E}-13$ \\
\hline 2013 & 0.7138 & $2.2 \mathrm{E}-16$ & 0.4868 & $4.795 \mathrm{E}-13$ \\
\hline 2014 & 0.7166 & $2.2 \mathrm{E}-16$ & 0.4873 & $4.509 \mathrm{E}-13$ \\
\hline
\end{tabular}

I - Moran's global statistic (see formula 1). 
Moran's global statistics / for the two study variables are positive and statistically significant ( $p$-value figures for positive values of $I$ statistics are significant when they are smaller than the set level of significance - the most commonly used level is 0.05 ). Higher values of statistics are observed in the case of GDP per inhabitant calculated in euro, which is justified. The obtained values unambiguously confirm the existence of a positive spatial autocorrelation, i.e. the clustering of regions displaying similar variable values within a particular location. A closer look at the values of $I$ statistics throughout the entire ten year period also reveals certain insignificant fluctuations, especially in the case of GDP_PPS variable (a slight weakening of the spatial interdependence can be seen over the study period).

An important element of spatial analysis is also the study of autocorrelation with the use of local statistics. For this purpose, Moran's local statistics $l_{i}$ has been applied in this paper. The results of the analysis are shown in Fig. 3, 4. The figures present clusters as well as non-typical areas in the years 2005, 2009 and 2014 for the two considered variables respectively.
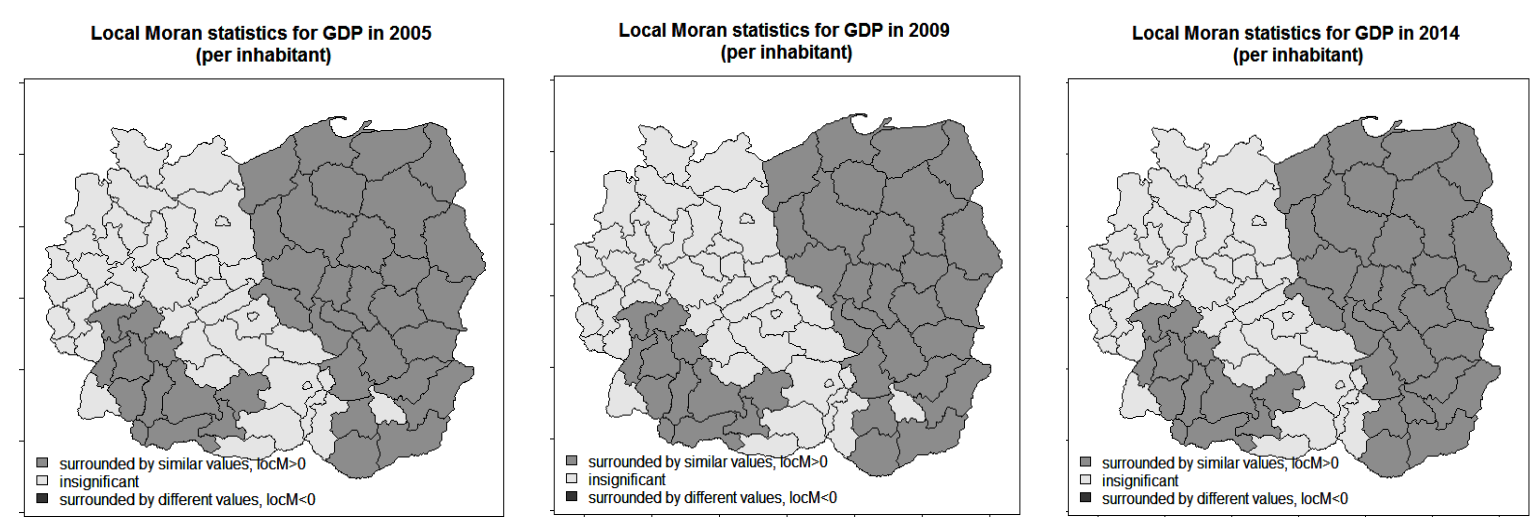

Fig. 3. Local Moran statistics for GDP_Euro $(2005,2009,2014)$
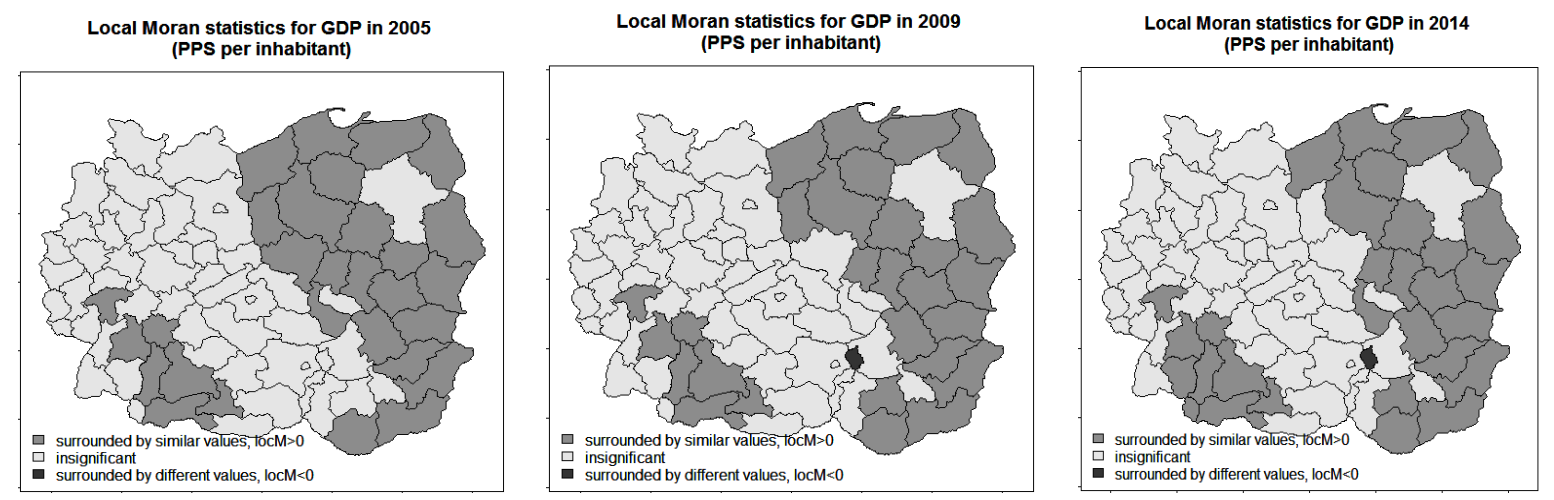

Fig. 4. Local Moran statistics for GDP_PPS $(2005,2009,2014)$

GDP per inhabitant in euro showed a clear tendency of clustering over the period studied. Two clusters are easily discernible. One is a cluster located in the south-western part of the area (including regions of south-western Germany and western Austria). This cluster is formed by regions of similar - high values of GDP per inhabitant (over 30000 euro). The second distinct cluster is located in the eastern part of the studied area and covers all 
regions of Poland and most regions of Slovakia, Hungary, as well as eastern regions of the Czech Republic (GDP oscillated around several thousand euro). A characteristic feature of this variable is the absence of even a single outlier throughout the study period - low and high values clustered and did not form any of the so-called 'lonely islands' adjacent to regions performing better or worse in terms of the studied feature.

The second variable - GDP per inhabitant in PPS also demonstrated clustering tendencies. The clusters are located in similar geographical area, though their amount is lower. What seems to be significant is the fact that, within the considered period, very few outliers were detected. In fact, in this case only one outlier was observed - the Bratislavian region for which the values of GDP per inhabitant in PPS were high (over 30000 euro), which definitely set it apart from neighbouring regions.

\section{CONCLUSION}

The main aim of the analysis was to identify spatial interdependence for variables most frequently used in the evaluation of economic development. The considered measure was GDP per inhabitant, which was examined in two forms - the first analysed the values (their levels and distribution) in euro currency, whereas the second studied GDP in PPS, i.e. expressed in an artificial currency in which the values are given after adjustment of national price differences using PPPs. In the first stage of the analysis we defined descriptive statistics for the whole ten year period of study and subsequently, constructed a typical area of variability for the variables, and presented the development of GDP levels in particular regions. Within the regions selected, the situation presented itself as follows: high values (above the average) were observed in the countries of the former western block (western Germany, Austria), whilst lower values (below the average) were observed for the central and eastern parts of the examined area. Inclusion of descriptive characteristics calculated from the entire period allowed to compare changes in GDP per inhabitant which took place over the study period. Positive changes were observed in the GDP level - its values consistently increased throughout the period. Similarly, positive changes could be noticed for GDP expressed in PPS.

Next, a spatial analysis was conducted with the use of global and local statistics. It allowed us to identify existing spatial interdependences and pinpoint clusters of regions with similar variable values, as well as non-typical regions whose development contrasted with that of the neighbouring regions. The analysis performed confirmed the existence of a strong spatial interdependence between the considered characteristics and clustering of regions with similar variable values. This tendency was demonstrated throughout the entire study period. Based on the research findings, it can be suggested that the observed tendency will continue in the coming years.

One may conclude that the level of economic development measured both by GDP per inhabitant and GDP per inhabitant in PPS (purchasing power standard) clearly demonstrates spatial interdependences. The use of spatial statistical tools has thus been helpful and fully justified. 


\section{REFERENCES}

Anselin L. 1995. Local indicators of spatial association - LISA. Geograph. Anal. 27(2), 93-115.

Cliff A.D., Ord J.K. 1973. Spatial autocorrelation. London, Pion.

Ekonometria przestrzenna. Metody i modele analizy danych przestrzennych. 2010. Red. B. Suchecki. Warszawa, C.H. Beck. [in Polish]

Kopczewska K. 2011. Ekonometria i statystyka przestrzenna z wykorzystaniem programu R Cran. Warszawa, CeDeWu.pl. [in Polish]

Makro- i mikroekonomia. Podstawowe problemy współczesności. 2013. Red. S. Marciniak. Warszawa, PWN. [in Polish]

Paelinck J.H.P., Klaassen L.H. 1983. Ekonometria przestrzenna. Warszawa, PWN, 14-22. [in Polish]

Pietrzykowski R. 2011. Wykorzystanie metod statystycznej analizy przestrzennej w badaniach ekonomicznych [The use of statistical methods for spatial analysis in the study of economic]. Rocz. Ekon. Kujaw.-Pomor. Szk. Wyż. Bydg. 4, 97-112. [in Polish]

Pośpiech E. 2015. Analiza przestrzenna bezrobocia w Polsce [Spatial analysis of unemployment in Poland]. Stud. Ekonom. 227, 59-74. [in Polish]

Pośpiech E., Mastalerz-Kodzis A. 2015. Autokorelacja przestrzenna wybranych charakterystyk społeczno-ekonomicznych [Spatial autocorrelation of selected social and economic characteristics]. Quant. Meth. Econom. 16(4), 85-94. [in Polish]

Tobler W. 1970. A computer model simulating urban growth in Detroit Region. Econom. Geogr. 46(2), 234-240.

Zeug-Żebro K. 2014. Analiza przestrzenna procesu starzenia się polskiego społeczeństwa [Spatial analysis of aging the Polish society]. Stud. Pr. Wydz. Nauk Ekonom. Zarządz. 36(2), 441-456. [in Polish]

Data base, http://ec.europa.eu/eurostat/web/regions/data/database, access: 10.06.2016.

Summary. The paper analyses per capita GDP - one of the most frequently used aggregate measures of economic development. This variable was examined as GDP expressed in euro and in PPS. The analysis included regions of six EU countries selected according to NUTS 2 system. The first stage of the analysis focused on the behaviour of per capita GDP over the ten year study period and revealed positive changes in GDP values over the entire research period. Next, the occurrence of spatial autocorrelation (both global and local) for the considered features was examined. The analysis demonstrated a strong, positive spatial autocorrelation throughout the study period and occurrence of two distinct clusters located respectively: in the eastern part of the research area (a cluster featuring lower than medium levels of GDP per inhabitant) and in the south-western area (a cluster featuring high levels of GDP per inhabitant). The analyses conducted confirmed the importance of the spatial factor in studies of economic development. 